\title{
Pengembangan Subject Specific Pedagogy Berbasis Inkuiri untuk Meningkatkan Keterampilan Proses dan Motivasi Belajar IPA
}

\author{
Setiti Handayani ${ }^{1}{ }^{*}$, Insih Wilujeng ${ }^{2}$ \\ ${ }^{1}$ SMP Negeri 2 Kembang Jepara. Jl. Raya Cepogo Kembang Jepara, Jawa Tengah, Indonesia. \\ ${ }^{2}$ Universitas Negeri Yogyakarta. Jl. Colombo No. 1 Karangmalang, Yogyakarta, Indonesia. \\ * Korespondensi Penulis. E-mail: hsetiti@yahoo.com \\ Received:10 January 2017; Revised:10 March 2017; Accepted: 10 April 2017
}

\begin{abstract}
Abstrak
Penelitian ini bertujuan untuk: (1) mengembangkan subject specific pedagogy (SSP) berbasis inkuiri sehingga layak digunakan dalam pembelajaran IPA kelas VII, (2) mengetahui peningkatan keterampilan proses siswa, dan (3) mengetahui peningkatan motivasi belajar IPA siswa SMP setelah menggunakan SSP berbasis inkuiri. Metode yang digunakan dalam penelitian ini adalah Research and Development ( R \& D) yang dikembangkan Borg \& Gall. Langkah pengembangan meliputi studi pendahuluan, perencanaan, penyusunan draf SSP dan validasi, uji coba terbatas, evaluasi dan revisi, uji coba lapangan menggunakan one-shot case study, revisi produk berdasarkan uji coba lapangan, dan produk akhir. Subjek coba pada penelitian ini adalah siswa SMPN 2 Kembang Jepara. Pengumpulan data dilakukan melalui angket, observasi, dan tes. Hasil penelitian menunjukkan bahwa: (1) SSP berbasis inkuiri yang dikembangkan (silabus, RPP, LKS, dan lembar penilaian) telah melalui tahapan validasi, uji coba terbatas, dan uji coba lapangan sehingga layak digunakan dalam pembelajaran IPA, (2) SSP dapat meningkatkan keterampilan proses, meliputi keterampilan mengamati, menyusun hipotesis, menganalisis data, mengkomunikasikan, dan mengambil kesimpulan, (3) SSP dapat meningkatkan motivasi belajar IPA siswa, meliputi tingkat keyakinan diri, strategi pembelajaran aktif, nilai belajar IPA, tujuan belajar IPA tujuan prestasi, dan dukungan lingkungan pembelajaran.
\end{abstract}

Kata Kunci: pengembangan, SSP, inkuiri, keterampilan proses, motivasi belajar IPA

\section{The Development of Inquiry-Based Subject Specific Pedagogy to Improve Process Skills and Science Learning Motivation}

\begin{abstract}
The study was conducted: (1) to develop inquiry-based SSP which was suitable for science learning at grade seven, (2) to know the improvement of students' process skills, and (3) to know students' motivation improvement on science learning after using inquiry-based SSP. The study was a Research and Development $(R \& D)$ developed by Borg \& Gall. The steps of the development included: preliminary study, planning, construction of SSP draft and validation, small-scale field testing, evaluation and revision, main field testing using one-shot case study, revision based on main field testing, and the final product. The subject of the study were the students of SMP N 2 Kembang Jepara. The data were collected through questionnaires, observations, and tests. The results show that: (1) SSP (the syllabus, lesson plans, student's worksheets, and evaluation sheets) which were developed through validation, preliminary field testing and main field testing, were good for science learning, (2) SSP can improve students' process skills i.e: observing, hypothesising, analysing of data, communicating, and drawing conclusions, (3) SSP can improve the students' learning science motivation, i.e: self efficacy, active learning strategies, science learning value, perfomance goal, achievement goal, and learning environment stimulation.
\end{abstract}

Keywords: development, SSP, inquiry, process skills, learning science motivation

How to Cite: Handayani, S., \& Wilujeng, I. (2017). Pengembangan subject specific pedagogy berbasis inkuiri untuk meningkatkan keterampilan proses dan motivasi belajar IPA. Jurnal Pendidikan Matematika dan Sains, 5(1). doi:http://dx.doi.org/10.21831/jpms.v5i1.13537

Permalink/DOI: DOI: http://dx.doi.org/10.21831/jpms.v5i1.13537 


\section{PENDAHULUAN}

IPA merupakan tubuh pengetahuan (body of knowledge) yang dibentuk melalui proses inkuiri secara terus-menerus, yang diarahkan oleh masyarakat yang bergerak dalam bidang IPA (Trowbridge \& Bybee, 1986, p.39). IPA tidak hanya kumpulan pengetahuan tentang benda atau makhluk hidup, tetapi merupakan cara kerja, cara berpikir, dan cara memecahkan masalah (Carin \& Sund, 1993, pp.4-5). Hakikat IPA meliputi 4 dimensi, yaitu (1) sikap: rasa ingin tahu tentang benda, fenomena alam, makhluk hidup, serta hubungan sebab akibat yang menim-bulkan masalah baru yang dapat dipecahkan melalui prosedur yang benar; (2) proses: prosedur pemecahan masalah melalui metode ilmiah, yang meliputi penyusunan hipotesis, perancangan eksperimen atau percobaan, evaluasi, pengu-kuran, dan penarikan kesimpulan; (3) produk: berupa fakta, prinsip, teori, dan hukum; (4) aplikasi: penerapan metode ilmiah dan konsep IPA dalam kehidupan sehari-hari (Collete \& Chiapetta, 1994, pp.3341).

Pendidikan IPA di (SMP) sesuai Kurikulum Tingkat Satuan Pendidikan (KTSP) dan Kurikulum 2013 (Kemdikbud, 2013, p.97) merupakan pembelajaran IPA secara terpadu dalam tema/topik. Pembelajaran IPA terpadu menghubungkan atau menyatupadukan berbagai bidang kajian IPA menjadi satu kesatuan bahasan. Terdapat empat model yang potensial untuk diterapkan dalam pembelajaran IPA terpadu, yaitu connected, webbed, shared, dan integrated. Empat model tersebut dipilih karena konsep-konsep dalam Kompetensi Dasar (KD) IPA memiliki karakteristik yang berbeda-beda, sehingga memerlukan model yang sesuai agar memberikan hasil yang optimal.

Pembelajaran terpadu tidak hanya memadukan bidang kajian saja, tetapi juga harus mencakup dimensi sikap, proses, produk, aplikasi, dan kreativitas. Hal ini sejalan dengan a new taxonomy of science education yang menyatakan bahwa pendidikan IPA dewasa ini mencakup lima dimensi, yaitu: 1) dimensi pengetahuan dan pemahaman, 2) penggalian dan penemuan, 3) imaginasi dan kreativitas, 4) sikap, dan 5) penerapan (McCormack, 1992, p.24).

Wawancara terhadap guru di SMPN 2 Kembang Jepara menyatakan bahwa pembelajaran IPA di SMP tersebut masih dibahas secara parsial melalui bidang kajian fisika, kimia, dan biologi. Beberapa faktor yang menjadi penye-babnya antara lain adalah kekurangpahaman guru terhadap pembelajaran terpadu dan belum banyak contoh konkrit perangkat pembelajaran IPA terpadu yang dapat diaplikasikan (Supriana, 2010, p.90).

Pembelajaran terpadu tidak hanya memadukan bidang kajian saja, tetapi juga harus mencakup dimensi sikap, proses, produk, aplikasi, dan kreativitas. IPA sebagai proses, maka siswa belajar melalui keterampilan-keterampilan seperti mengamati, menyimpulkan, dan melakukan eksperimen. Proses IPA penting dikuasai siswa sejak di SD (Semiawan et. al., 1989, pp.14-15) karena: 1) ilmu pengetahuan berkembang sangat cepat sehingga tidak mungkin lagi menga-jarkan fakta dan konsep kepada siswa; 2) siswa lebih mudah memahami konsep abstrak apabila belajar melalui bendabenda konkret dan lang-sung melakukan sendiri; 3) penemuan ilmu pengetahuan sifat kebenarannya relatif; dan 4) dalam pembelajaran, pengembangan konsep tidak dapat dipisahkan dari pengembangan sikap dan nilai. Proses pembelajaran yang berorientasi pada ujian mengakibatkan IPA sebagai proses tidak tersentuh dalam proses pembelajaran. Bundu (2006, p.1) menyatakan bahwa fokus penilaian Ujian Nasional (UN) masih pada dimensi isi (produk IPA) berupa konsep-konsep IPA, belum menyentuh pada dimensi proses IPA. Proses pembelajaran IPA harus memberikan pengalaman langsung terhadap bidang kajian yang dipelajari.

Terkait dengan keterampilan proses IPA, Padilla (1990, p.1) menyatakan "these skills are defined as a set of broadly transferable abilities, appropiate to many science disciplines and reflective of the behavior of scientist", artinya keterampilan proses merupakan seperangkat kemampuan luas yang ditransfer, sesuai untuk semua IPA dan mencerminkan perilaku ilmuwan. Collete \& Chiappetta (1994, p.89) menyatakan bahwa keterampilan proses memfokuskan pada banyak keterampilan dalam diri manusia yang digunakan untuk mengkonstruksi pengetahuan. Rezba et. al. (1995, p.vii) menyatakan "the science process skills are the things that scientists do when they study and investigate". Keterampilan proses IPA merupakan hal-hal yang dilakukan ilmuwan ketika sedang belajar dan menyelidiki.

Keterampilan proses IPA merupakan sejumlah keterampilan untuk mengkaji fenomena alam dengan cara-cara tertentu untuk mem-peroleh ilmu dan pengembangan ilmu 
selan-jutnya. Siswa dengan keterampilan proses dapat mempelajari IPA sesuai dengan yang para ahli IPA lakukan, yaitu melalui pengamatan, klasi-fikasi, inferensi, merumuskan hipotesis, dan melakukan eksperimen (Bundu, 2006, p.12). Dengan demikian keterampilan proses tidak terpisahkan dari kegiatan yang berhubungan dengan IPA. Hal ini sesuai dengan pernyataan Keil, Haney \& Zoffel (2009, p.4) "science process skills are inseparable from the pratice of science and play a key role in both formal and informal learning of science content", artinya keterampilan proses IPA tidak dapat dipisahkan dari pelaksanaan IPA dan berperan penting pada pembelajaran IPA baik formal maupun non-formal. Pernyataan sejenis juga diungkapkan oleh Harlen (1999, p.129) dan Karamustafaoğlu (2010, p.26) "science process skills are inseparable in pratice from the conceptual understanding that is involved in learning and applying science", artinya keterampilan proses tidak dapat dipisahkan dalam praktek memahami konsep dalam pembelajaran dan penerapan IPA.

Secara operasional, keterampilan proses dalam pembelajaran IPA merupakan suatu model atau alternatif pembelajaran yang dapat melibat-kan siswa dalam tingkah laku dan proses mental seperti ilmuwan. Keterampilan proses merupa-kan keseluruhan keterampilan ilmiah yang ter-arah (baik kognitif maupun psikomotor) yang dapat digunakan untuk menemukan suatu konsep atau prinsip atau teori, untuk mengembangkan konsep yang telah ada sebelumnya, ataupun untuk melakukan penyangkalan terhadap suatu penemuan.

Terkait dengan implementasi dalam pembelajaran, Padilla (1990, p.1) membagi keterampilan proses menjadi dua, yaitu (1) keterampilan proses dasar: observing, classifying, measuring, communicating, inferring, predicting; (2) keterampilan proses terpadu: defining operationally, formulating models, controlling variables, interpreting data, hypothesizing, experimenting. Rezba et. al. (1995, p.1) menyatakan bahwa keterampilan proses dasar meliputi observasi, prediksi, membuat dugaan, klasifikasi, komunikasi, dan pengukuran. Keterampilan proses terintegrasi (Rezba et. al., 1995, p.117) meliputi identifikasi variabel, membuat hipotesis, analisis investigasi, tabulasi, membuat grafik, menentukan variabel, investigasi, dan melakukan eksperi-men.

Hal senada juga dikemukakan oleh Chiapetta \& Koballa (2010, p.132) bahwa keterampilan proses dibagi menjadi: 1) keterampilan proses dasar (basic process skills) meliputi observasi, klasifikasi, hubungan ruang/waktu, penggunaan angka, mengukur, menarik kesimpulan, dan prediksi; 2) keterampilan proses terintegrasi (integrated process skills) meliputi definisi operasional, membuat model, mengontrol variabel, interpretasi data, merumuskan hipo-tesis, dan eksperimen. Berdasarkan analisis ma-teri dan pendekatan inkuiri, keterampilan proses yang dinilai dalam penelitian ini adalah keteram-pilan merumuskan hipotesis, mengamati, meng-analisis data, mengkomunikasikan dan mengam-bil kesimpulan.

Selain keterampilan proses, pembelajaran IPA juga harus memperhatikan komponen afektif siswa, salah satunya adalah motivasi belajar IPA, yang mempunyai peranan penting dalam proses perubahan konsep siswa. Kehidupan abad 21 yang kompleks membutuhkan pengembangan kemampuan, kualitas dan watak pembelajaran sepanjang hidup. Hal ini menyebabkan penting-nya mencakup motivasi belajar sebagai salah satu tujuan pendidikan pada semua level (Harlen \& Crick, 2003, p.173). Motivasi belajar merupakan proses aktivitas yang mendorong untuk mencapai tujuan belajar dan dilakukan terus menerus (Schunk, Pintrich, \& Meece, 2010, p.4). Teori konstruktivis menjelaskan bahwa siswa harus berperan aktif dalam membangun pengetahuan-nya. Siswa ketika merasa berarti dan berharga dalam tugas belajar, akan secara aktif terlibat belajar, menggunakan strategi belajar aktif untuk memadukan pengetahuannya dengan pengalam-an yang baru.

Motivasi merupakan salah satu faktor dalam diri siswa yang mempengaruhi keefektifan belajar di kelas. Schunk, Pintrich \& Meece (2010, p.41) menyatakan bahwa motivasi memiliki hubungan dengan kemampuan belajar. Motivasi merupakan suatu hubungan timbal balik dengan proses dan kemampuan belajar. Artinya, motivasi dapat mempengaruhi proses belajar, dan sebaliknya, proses belajar juga dapat mem-pengaruhi motivasi siswa. Chang \& Chang (2012, p.281) menjelaskan bahwa motivasi merupakan rangsangan secara psikis yang memicu tingkah laku individu untuk mencapai tujuan tertentu. Dengan demikian dapat disimpulkan bahwa motivasi belajar merupakan dorongan dari dalam dan luar diri diri siswa untuk membangun pengetahuan baru, dilakukan secara terus-menerus. 
Motivasi belajar yang ditingkatkan dalam penelitian ini mengadopsi motivasi belajar IPA yang dikembangkan Tuan, Chin, \& Shieh. Tuan, Chin, \& Shieh (2005a, p.641) menyatakan bahwa motivasi belajar IPA siswa terdiri dari tingkat keyakinan diri, strategi belajar aktif, nilai belajar IPA, tujuan belajar IPA, tujuan prestasi, dan lingkungan belajar yang mendukung. Tingkat keyakinan diri berhubungan dengan kepercayaan siswa terhadap kemampuannya untuk menger-jakan tugas belajar IPA dengan baik. Strategi belajar aktif menyatakan bahwa siswa berperan aktif menggunakan berbagai strategi belajar untuk membangun pengetahuan baru berdasar-kan pemahaman sebelumnya.

Nilai belajar IPA bertujuan membiarkan siswa memperoleh kompetensi memecahkan masalah, pengalaman aktivitas inkuiri, menstimulasi cara berpikir, dan mendapatkan hubungan IPA dengan kehidupan sehari-harinya. Jika siswa dapat memperoleh nilai penting ini, maka siswa akan termotivasi untuk belajar IPA. Tujuan siswa belajar IPA adalah untuk bersaing dengan siswa lain dan mendapat perhatian dari gurunya. Tujuan prestasi berhubungan dengan kepuasan siswa ketika mereka dapat meningkatkan kompetensi dan prestasinya selama belajar IPA. Lingkungan belajar siswa di kelas berhubungan dengan kurikulum, cara guru mengajar, dan interaksi siswa dengan yang lainnya.

Berdasarkan uraian sebelumnya dapat disimpulkan bahwa motivasi belajar IPA memiliki peranan penting dalam mendukung keberhasilan belajar. Akan tetapi hal tersebut kontradiksi dengan fakta yang terjadi di lapangan. Berdasarkan hasil wawancara terhadap guru IPA dan observasi pembelajaran IPA di SMP N 2 Kembang Jepara menunjukkan bahwa motivasi belajar siswa terhadap IPA masih ren-dah. Guru mendominasi pembelajaran (teacher centered) dan siswa tidak terlibat aktif di dalamnya. Siswa diam untuk mendengarkan penjelasan guru dan enggan bertanya apabila mengalami kesulitan dalam memahami materi IPA.

Sehubungan dengan kondisi tersebut, maka diperlukan pembelajaran yang membelajarkan IPA secara holistik dan tidak hanya mempelajari IPA sebagai produk, tetapi juga dapat meningkatkan keterampilan proses dan motivasi belajar IPA siswa. Salah satu pendekatan yang diduga dapat meningkatkan keterampilan proses dan motivasi belajar adalah pendekatan inkuiri. Kemdikbud (2013, p.3) menyebutkan bahwa untuk memperkuat pendekatan ilmiah (scientific), tematik terpadu (tematik antarmata pelajaran), dan tematik (dalam satu mata pelajaran) perlu diterapkan pembelajaran berbasis penyingkapan/penelitian (discovery/ inquiry learning). Inkuiri merupakan proses mendefinisikan dan menyelidiki masalah, meru-muskan hipotesis, merancang eksperimen, mengumpulkan data, dan membuat kesimpulan tentang masalah tersebut (Trowbridge \& Bybee, 1986, p.183).

Simsek \& Kabapinar (2010, p.1190) menyatakan bahwa pembelajaran berbasis inkuiri memberikan pengaruh positif terhadap pema-haman konsep dan keterampilan proses siswa. Hasil penelitian tersebut didukung oleh Ergül et. al. (2011, p.48) yang menyatakan bahwa pem-belajaran berbasis inkuiri dapat meningkatkan keterampilan proses siswa secara signifikan. Pembelajaran inkuiri berusaha membantu siswa belajar dan memperoleh pengetahuan serta membangun konsep-konsep secara mandiri. Melalui pembelajaran berbasis inkuiri, secara perlahan siswa dapat belajar cara meng-organisasikan dan mengadakan penelitian secara independen agar konsep yang didapatkan mudah diingat oleh siswa. Oleh karena itu, penting untuk membelajarkan IPA menggunakan pendekatan inkuiri.

Secara operasional Collete dan Chiappetta (1994, p.86) menjelaskan inkuiri dapat dipandang sebagai dua cara dalam pembelajaran IPA, yaitu teaching science as inquiry dan teaching science through inquiry. Teaching science as inquiry mengharuskan guru untuk memahami sifat dasar dari IPA dan cara pengetahuan diperoleh. Teaching science through inquiry mengarah pada keterampilan dan strategi. Metode ini sering diintegrasikan ke dalam proses pembelajaran untuk mendorong siswa melalui kegiatan-kegiatan berikut: bertanya, keterampilan proses IPA, aktivitas induktif, aktivitas deduktif, mengumpulkan informasi dan menyelesaikan masalah.

Pendekatan inkuiri ditandai dengan adanya pencarian jawaban yang mensyaratkan siswa melakukan serangkaian kegiatan intelektual agar pengalaman atau masalah dapat dipahami. Inkuiri menekankan adanya inisiatif dari siswa untuk mengalami proses belajarnya sendiri. Pembe-lajaran dengan pendekatan inkuiri tidak hanya menekankan pada pemahaman konsep, tetapi juga keterampilan proses siswa. Yager \& Akcay (Ergul et. al., 2011, p.49) menyatakan bahwa "inquiry is 
defined as an approach to teaching, the acts scientist use in doing science and it can be a highly effective teaching methode that help students for to understanding of concepts and proccess skills." Dengan demikian dapat disimpulkan bahwa inkuiri merupakan suatu proses untuk memecahkan masalah dengan menggunakan metode ilmiah sehingga siswa dapat menemukan sendiri pengetahuannya.

Terkait dengan implementasi inkuiri dalam pembelajaran, Joyce, Weil, \& Calhoun (2004, p.122) menjelaskan bahwa sintaks inkuiri meliputi: 1) confrontation with the problem (penyajian masalah), 2) data gathering-verification (pengumpulan dan verifikasi data), 3) data gathering-experimentation (melakukan eksperimen), 4) organizing, formulating an explanation (merumuskan penjelasan), 5) analysis of the inquiry process (analisis terhadap proses inkuiri). Sedangkan Dell'Olio \& Donk (2007, p.330), menyatakan bahwa siklus inkuiri adalah melalui proses penerapan metode ilmiah dalam pembelajaran. Urutan metode ilmiah ditentukan sebagai berikut: 1) mengembangkan pertanyaan, 2) membangkitkan sebuah hipotesis, 3) mengem-bangkan desain eksperimen, 4) mengumpulkan dan mencatat data, 5) menganalisis data, 6) kesimpulan dan generalisasi, 7) mengkomuni-kasikan hasil.

Masih terkait sintaks pembelajaran inkuiri, pendapat lain dikemukakan oleh Moore (2009, p.184) yang membagi lima fase urutan inkuiri dalam pembelajaran, yaitu: 1) engage, siswa mengidentifikasi tugas pembelajaran, 2) explore, siswa mengembangkan pengalamannya dengan fenomena dan objek, 3) explain, siswa terlibat dalam analisis eksplorasinya, 4) elaborate, siswa memperluas konsep yang telah dipelajari, membuat koneksi ke konsep terkait lainnya, dan menerapkan pemahamannya terhadap dunia di sekitarnya, 5) evaluate, guru menentukan penca-paian siswa dalam memahami konsep tentang pengetahuan IPA.

Berdasarkan pendapat-pendapat para ahli tersebut, maka diperoleh sintesis langkah pembe-lajaran inkuiri yang dilakukan dalam penelitian ini adalah: 1) merumuskan masalah, guru menunjukkan suatu permasalahan kepada siswa melalui tayangan gambar atau video; 2) merumuskan hipotesis, siswa merumuskan hipotesis berdasarkan rumusan masalah yang diberikan guru; 3) mengumpulkan data yang relevan untuk memecahkan masalah; 4) menganalisis data, siswa belajar menjelaskan penalarannya agar dapat mendukung validitas ana- lisis; 5) mengambil kesimpulan, guru membimbing siswa pada pemahaman yang lebih mendalam dan siswa dapat membandingkan hasilnya dengan hipotesis yang telah disusun.

Penyampaian pembelajaran IPA yang berbasis inkuiri untuk meningkatkan keterampilan proses dan motivasi belajar harus terstruktur dan bersifat khusus. Pelaksanaan pembe-lajaran memerlukan suatu komponenkomponen yang khusus yang dikenal dengan Subject Spesific Pedagogy (SSP). SSP mempunyai makna yang sama dengan Pedagogical Content Knowledge (PCK) seperti yang dinyatakan Shulman (1987, p.8). PCK berhubungan dengan content knowledge (CK) dan pedagogical knowledge (PK). Koehler \& Mishra (2009, p.63) menyatakan bahwa PCK merupakan gagasan tentang transformasi materi pembelajaran, terjadi ketika guru menafsirkan materi pembelajaran, menyampaikan materi dengan berbagai cara, menyesuaikan dan membuat bahan pembelajaran untuk konsepsi alternatif dan pengetahuan siswa sebelumnya.

Pengembangan SSP tidak pernah lepas dari pengetahuan tentang konten dan pedagogi (content \& pedagogical knowledge). Beberapa elemen kunci pengetahuan yang berhubungan dengan isi pedagogi, yaitu: 1) pengetahuan tentang gambaran subjek materi; 2) pemahaman siswa dan implikasi belajar mengajar yang berhubungan dengan subjek tertentu; 3) pengetahuan umum pedagogi (strategi mengajar); 4) pengetahuan kurikulum; 5) pengetahuan tentang konteks pendidikan; dan pengetahuan tentang tujuan pendidikan.

SSP merupakan suatu bentuk pengetahuan guru dan suatu bagian dari poses berpikir guru. SSP bersifat dinamis, karena dapat mengalami perubahan dalam merespon mata pelajaran dan siswa. SSP menjadi penengah antara perkembangan penguasaan mata pelajaran dengan perubahan lingkungan untuk pengajaran. Secara lebih spesifik, SSP merupakan pengemasan materi bidang studi menjadi perangkat pembelajaran yang mendidik yang komprehensif dan solid yang mencakup standar kompetensi, kompetensi dasar, materi metode, strategi, media, dan eva-luasi. SSP yang dikembangkan dalam penelitian ini terdiri atas silabus, RPP, LKS, dan instrumen penilaian siswa. Beberapa peneliti telah mengem-bangkan SSP, diantaranya penelitian yang dilakukan oleh Noor \& Wilujeng (2015) dengan hasil penelitian menunjukkan bahwa pengem-bangan SSP memenuhi kriteria valid dengan kategori sangat 
baik, keterbacaan buku dan LKS berada pada kategori baik, dan kenaikan skor aspek keterampilan proses dan motivasi belajar siswa pada pembelajaran menggunakan SSP lebih baik dibandingkan pembelajaran konven-sional.

Terkait permasalahan yang telah dikemukakan berikut kajian teorinya, maka tujuan penelitian ini adalah untuk: 1) mengetahui kelayakan SSP berbasis inkuiri yang dikembangkan, 2) mengetahui peningkatan keterampilan proses siswa SMP setelah pembelajaran menggunakan SSP berbasis inkuiri yang dikembangkan, dan 3) mengetahui peningkatan motivasi belajar siswa SMP setelah pembelajaran menggunakan SSP berbasis inkuiri yang dikembangkan.

\section{METODE}

Penelitian ini merupakan penelitian Research and Development ( $\mathrm{R} \& \mathrm{D})$ yang bertujuan menghasilkan produk berupa SSP berbasis inkuiri untuk meningkatkan keterampilan proses dan motivasi belajar IPA siswa SMP. Komponen SSP yang dikembangkan meliputi silabus, RPP, LKS, dan lembar penilaian siswa. Penelitian ini dilaksanakan selama 7 bulan, dari September 2013 sampai April 2014 di SMP N 2 Kembang Jepara.

\section{Prosedur Penelitian}

Penelitian menggunakan model pengembangan yang dikembangkan oleh Borg \& Gall (Gall, Gall, \& Borg, 2007, p.589). Langkahlangkah utama R \& D meliputi: (1) mengumpulkan informasi dan penelitian pendahuluan; (2) melakukan perencanaan; mengembangkan bentuk produk awal; (4) melakukan uji coba terbatas produk awal untuk menghasilkan produk utama; (5) melakukan revisi terhadap produk utama; (6) melakukan uji coba produk utama; (7) melakukan revisi terhadap produk utama untuk menghasilkan produk final; (8) melakukan uji coba lapangan produk final; (9) melakukan revisi terhadap produk final; dan (10) mendiseminasi dan mengimplementasikan produk. Prosedur penelitian ini diadaptasi dari Borg dan Gall dengan melakukan modifikasi, yaitu: (1) tahap studi pendahuluan, (2) tahap desain produk, (3) tahap validasi, (4) tahap uji coba dan revisi produk, dan (5) tahap produk akhir.

\section{Desain Uji Coba}

Uji coba produk pada penelitian ini terdiri dari 2 tahapan, yaitu: uji coba terbatas dan uji coba lapangan. Uji coba lapangan menggunakan desain one-shot case study yang diadopsi dari Suharsimi (2010, p.124).

\begin{tabular}{|ll|}
\hline $\mathrm{X}$ & $\mathrm{O}$ \\
\hline
\end{tabular}

Gambar 1. Desain One-Shot Case Study

\section{Keterangan: \\ Pembelajaran IPA berbasis inkuiri \\ Skor motivasi belajar dan keterampilan proses}

\section{Subjek Uji Coba}

Subjek uji coba penelitian ini adalah siswa kelas VII di SMP N 2 Kembang Jepara semester 2 tahun ajaran 2013/2014. Subjek uji coba terbatas berjumlah 12 siswa dari kelas yang tidak digunakan untuk penelitian.

\section{Teknik dan Instrumen Pengumpulan Data}

Teknik pengumpulan data yang digunakan dalam penelitian ini adalah observasi, angket, dan tes. Instrumen lembar penilaian kelayakan SSP digunakan untuk memperoleh data tentang saran atau komentar dan penilaian dari ahli materi, guru IPA, dan teman sejawat. Lembar observasi digunakan selama proses pembelajaran berlang-sung meliputi: 1) lembar observasi keterlak-sanaan pembelajaran, 2) lembar observasi moti-vasi belajar IPA, dan 3) lembar observasi untuk penilaian keterampilan proses.

Lembar angket dalam penelitian ini meliputi: 1) angket respon siswa, 2) angket moti-vasi belajar. Perhitungan validitas dan reliabilitas angket motivasi belajar IPA menggunakan bantuan komputer SPSS ${ }^{\mathrm{TM}}$ versi 16.0. Validitas angket dihitung dengan Corrected Item Total Correlation, sedangkan koefisien reliabilitas menggunakan rumus Alpha Cronbach. Wido-yoko (2012, p.180) menyatakan bahwa butir pernyataan dalam angket motivasi dikatakan valid apabila skornya lebih besar dari standar minimal $(0,3)$. Instrumen dikatakan reliabel apabila Alpha Cronbach lebih besar dari $\mathrm{r}$ tabel. Lembar soal digunakan untuk mengetahui kete-rampilan proses siswa dalam pembelajaran IPA. Validitas dan reliabilitas soal pilihan ganda dilakukan dengan program komputer ITEMAN 3.00.

\section{Teknik Analisis Data}


Data yang berupa komentar, saran dan revisi selama proses uji coba dianalisis secara deskritif kualitatif dan disimpulkan sebagai masukan untuk merevisi produk yang dikembangkan. Teknik analisis data yang berupa tanggapan ahli (kelayakan produk), skor respon siswa, skor keterlaksanaan RPP, skor motivasi belajar, dan skor keterampilan proses dilakukan sebagai berikut: 1) mentabulasikan semua data yang diperoleh dari validator untuk setiap komponen dari butir penilaian yang tersedia dalam instrumen penilaian, 2) menghitung skor total rata-rata setiap komponen, 3) mengubah skor menjadi skor standar 0-100, dan 4) mengubah skor rata-rata menjadi nilai dengan kriteria. Acuan pengubahan skor menurut Azwar (2011, p.163) disajikan pada Tabel 1.

Tabel 1. Konversi Skor Aktual Nenjadi Nilai Skala 5

\begin{tabular}{ccc}
\hline Interval Skor & Nilai & Kategori \\
\hline $\mathbf{X}>\mathrm{M}+1,5 \mathrm{~S}$ & $\mathbf{A}$ & Sangat baik \\
$\mathrm{M}+0,5 \mathrm{~S}<\mathbf{X} \leq \mathrm{M}+1,5 \mathrm{~S}$ & $\mathbf{B}$ & Baik \\
$\mathrm{M}-0,5 \mathrm{~S}<\mathbf{X} \leq \mathrm{M}+0,5 \mathrm{~S}$ & $\mathbf{C}$ & Cukup baik \\
$\mathrm{M}-1,5 \mathrm{~S}<\mathbf{X} \leq \mathrm{M}-0,5 \mathrm{~S}$ & $\mathbf{D}$ & Tidak baik \\
$\mathbf{X} \leq \mathrm{M}-1,5 \mathrm{~S}$ & $\mathbf{E}$ & $\begin{array}{c}\text { Sangat tidak } \\
\text { baik }\end{array}$ \\
\hline
\end{tabular}

Keterangan:

$X$ : Skor aktual

M: Rerata skor ideal

S : Simpangan baku ideal

Konversi skor menggunakan rerata ideal dan simpangan baku skor ideal karena penilaian SSP dan respon siswa menggunakan acuan patokan. SSP dikatakan layak digunakan untuk uji coba jika rata-rata skor setiap perangkat SSP mempunyai kategori cukup. Skor aktual dikonversi menjadi skor standar skala $0-100$, hasilnya disajikan pada Tabel 2.

Tabel 2. Konversi Skor Standar Menjadi Nilai Skala Lima

\begin{tabular}{ccc}
\hline Interval Skor & Nilai & Kategori \\
\hline $\mathbf{X}>80$ & A & Sangat baik \\
$66,75<\mathbf{X} \leq 80$ & B & Baik \\
$53,25<\mathbf{X} \leq 66,75$ & C & Cukup baik \\
$40<\mathbf{X} \leq 53,25$ & D & Tidak baik \\
$\mathbf{X} \leq 40$ & E & Sangat tidak baik \\
\hline
\end{tabular}

Reliabilitas observasi keterlaksanaan pem-belajaran dihitung dengan rumus koefisien kese-pakatan pengamatan dari Fernandes (Suharsimi, 2010, p.248).
$\mathrm{KK}=\frac{2 S}{N 1-N 2}$

Keterangan:

KK: koefisien kesepakatan pengamatan

$\mathrm{S}$ : sepakat, jumlah kode yang sama untuk objek yang sama

N1 jumlah kode yang dibuat oleh pengamat 1

N2 jumlah kode yang dibuat oleh pengamat 2

Analisis perbedaan keterampilan proses dan motivasi belajar IPA siswa, menggunakan gain standar (Meltzer, 2002: 3). Persamaan gain standar sebagai berikut:

$$
\text { Gain standar }=\frac{\text { skor postes }- \text { skor pretes }}{\text { skor maksimum }- \text { skor pretes }}
$$

Kriteria indeks gain standar menurut Hake (1998, p.3) dapat dilihat pada Tabel 3.

Tabel 3. Kriteria Indeks Gain Standar

\begin{tabular}{cc}
\hline Indeks Gain Standar & Kriteria \\
\hline $\mathrm{g}>0,70$ & Tinggi \\
$0,30<\mathrm{g} \leq 0,70$ & Sedang \\
$\mathrm{g} \leq 0,30$ & Rendah \\
\hline
\end{tabular}

\section{HASIL DAN PEMBAHASAN}

\section{Hasil Pengembangan}

Berdasarkan hasil analisis kurikulum, materi, dan konsep, tema yang diambil dalam penelitian ini adalah "Jernihnya Airku". Tema ini menggabungkan SK 2: Memahami klasifikasi zat, SK 4: Memahami berbagai sifat dalam perubahan fisika dan kimia, SK 7: Memahami saling ketergantungan dalam ekosistem. KD yang digabungkan adalah KD 2.1 Mengelompokkan sifat larutan asam, larutan basa, dan larutan garam melalui alat dan indikator yang tepat; KD 4.2 Melakukan pemisahan campuran dengan berbagai cara berdasarkan sifat fisika dan sifat kimia; dan KD 7.4 Mengaplikasikan peran manusia dalam pengelolaan lingkungan untuk mengatasi pencemaran dan kerusakan ling-kungan.

Pembelajaran IPA yang akan dilaksanakan pada penelitian ini menggunakan keterpaduan model connected. Pemilihan model ini karena tema yang digunakan memiliki keterhubungan antar SK dan KD beberapa bidang kajian IPA. Tema "Jernihnya Airku" mempelajari tentang pencemaran air (biologi) yang memiliki keter-kaitan dengan materi asam, basa, garam (kimia) dan pemisahan campuran secara filtrasi (fisika). Parameter kimia air 
tercemar dapat diketahui dengan cara mengukur pHnya dengan meng-gunakan indikator universal. Salah satu cara untuk mendapatkan air bersih adalah meng-gunakan pemisahan campuran secara filtrasi.

\section{Hasil Validasi SSP Berbasis Inkuiri}

Ringkasan hasil penilaian SSP oleh ahli, guru IPA dan teman sejawat disajikan pada Tabel 4. Berdasarkan Tabel 4, hasil penilaian SSP mendapatkan nilai A, dengan kriteria sangat baik. Secara keseluruhan dapat dinyatakan bahwa SSP hasil pengembangan layak diujicobakan dalam pembelajaran untuk meningkatkan keterampilan proses dan motivasi belajar IPA siswa SMP.

Soal pilihan ganda tes keterampilan proses juga divalidasi empiris menggunakan program ITEMAN 3.00. Soal pilihan ganda sejumlah 30 soal diujicobakan pada 31 siswa kelas VIII. Berdasarkan hasil analisis, terdapat 3 soal yang ditolak, 4 soal yang harus diperbaiki dan 23 soal diterima. Alpha sebesar 0,689, ini menunjukkan soal reliabel. Tingkat kesalahan pengukuran tinggi (SEM) yaitu 2,317, rata-rata tingkat kesukaran soal (Mean $P$ ) yaitu 0,784 (sedang) dan rata-rata daya pembedanya baik (Mean Biseral) yaitu 0,426.

Tabel 4. Hasil Validasi SSP

\begin{tabular}{lccc}
\hline Komponen SSP & Skor & Nilai & Kategori \\
\hline Silabus & 86 & A & Sangat baik \\
RPP & 86 & A & Sangat baik \\
LKS & 84 & A & Sangat baik \\
Soal Keterampilan & 85 & A & Sangat baik \\
$\begin{array}{l}\text { Proses } \\
\text { Angket Motivasi }\end{array}$ & 83 & A & Sangat baik \\
Belajar & \\
\hline
\end{tabular}

Angket motivasi belajar IPA juga divalidasi secara empiris dan diuji reliabilitasnya. Butir penyataan angket motivasi belajar IPA sejumlah 35 diujicobakan pada siswa kelas VIII sejumlah 30. Analisis angket motivasi belajar IPA menggunakan bantuan program komputer SPSS ${ }^{\mathrm{TM}}$ versi 16.0. Hasil analisis menunjukkan 9 butir pernyataan tidak valid, 26 butir pernyataan valid, ini dapat diketahui dari nilai corrected item total correlation lebih besar dari nilai 0,306. Nilai 0,306 merupakan nilai minimum kriteria soal yang valid, diperoleh dari tabel $\mathrm{r}$ product moment pearson dengan nilai degree of freedom 29. Apabila $r$ hitung $>r$ tabel maka butir pernyataan dikatakan valid. Butir pernyataan angket yang diujicobakan mempunyai koefisien reliabilitas (Alpha Cronbach's) sebesar 0,854, yang berarti angket motivasi belajar IPA yang dikembangkan berkategori reliabel.

\section{Hasil Uji Coba Keterampilan Proses}

Penilaian keterampilan proses pada uji coba terbatas diperoleh melalui instrumen lembar soal pilihan ganda, yang diberikan setelah pem-belajaran menggunakan SSP yang dikembangkan dan observasi. Hasil uji coba menunjukkan bahwa dari 12 subjek coba, ada 2 siswa (17\%) yang mendapatkan nilai A dengan kategori sangat baik, 5 siswa (42\%) mendapatkan nilai $\mathrm{B}$ dengan kategori baik, 3 siswa (25\%) menda-patkan nilai $\mathrm{C}$ dengan kategori cukup baik, dan 2 siswa (17\%) mendapatkan nilai D dengan kategori tidak baik. Rerata skor keterampilan proses siswa setelah menggunakan SSP berbasis inkuiri adalah 60,5 dengan kategori cukup baik.

Hasil observasi menunjukkan bahwa untuk keterampilan menyusun hipotesis, 2 siswa (17\%) mendapatkan nilai A kategori sangat baik, 8 siswa (67\%) mendapatkan nilai B kategori baik, dan 2 siswa (17\%) mendapatkan nilai D kategori tidak baik. Rerata skor keterampilan menyusun hipotesis adalah 75,6 kategori baik. Keterampilan mengamati, terdapat 2 siswa (17\%) mendapatkan nilai A dengan kategori sangat baik, 3 siswa (25\%) mendapatkan nilai $\mathrm{B}$ kategori baik, 4 siswa (33\%) mendapatkan nilai $\mathrm{C}$ kategori cukup baik, 2 (17\%) siswa mendapatkan nilai D dengan kategori tidak baik, dan 1 siswa (8\%) mendapatkan nilai $\mathrm{E}$ dengan kategori sangat tidak baik. Rerata skor keterampilan mengamati adalah 68,3 dengan kategori baik.

Keterampilan menganalisis data, 1 siswa (8\%) mendapatkan nilai A dengan kategori sangat baik, 4 siswa (33\%) mendapatkan nilai B kategori baik, 5 siswa (42\%) mendapatkan nilai $\mathrm{C}$ dengan kategori cukup baik, dan 2 siswa (17\%) mendapatkan nilai D dengan kategori tidak baik. Rerata skor keterampilan menganalisis data adalah 68,3 dengan kategori baik. Keterampilan mengkomunikasikan data, terdapat 3 siswa (25\%) mendapatkan nilai A dengan kategori sangat baik, 4 siswa (33\%) mendapatkan nilai $\mathrm{B}$ dengan kategori baik, 4 siswa (33\%) men-dapatkan nilai $\mathrm{C}$ dengan kategori cukup baik, dan 1 siswa (9\%) mendapatkan nilai D dengan kategori tidak baik. Rerata skor keterampilan mengkomunikasikan data adalah 72,8 dengan kategori baik. Keterampilan menyusun kesim-pulan, terdapat 2 
siswa (17\%) mendapatkan nilai A dengan kategori sangat baik, 4 siswa (32\%) mendapatkan nilai $\mathrm{B}$ dengan kategori baik, 2 siswa (17\%) mendapatkan nilai $\mathrm{C}$ dengan kategori cukup baik, 2 siswa (17\%) mendapatkan nilai $\mathrm{D}$ dengan kategori tidak baik, dan 2 siswa (17\%) mendapatkan nilai E dengan kategori sangat tidak baik. Rerata skor keterampilan menyusun kesimpulan adalah 64,5 dengan kategori cukup baik.

Peningkatan keterampilan proses siswa pada uji coba lapangan diukur melalui tes menggunakan instrumen lembar soal pilihan ganda, yaitu dengan cara menghitung gain standar dari hasil pretes dan postes. Pengukuran ini bertujuan mengetahui besarnya pengaruh perlakuan terhadap peningkatan keterampilan proses, disajikan pada Tabel 5. Berdasarkan Tabel 5, diketahui bahwa rerata skor keterampilan proses siswa sebelum menggunakan SSP berbasis inkuiri adalah 42,8 dengan kategori tidak baik. Rerata skor keterampilan proses setelah siswa menggunakan SSP berbasis inkuiri adalah 66,8 dengan kategori baik. Ini berarti terjadi peningkatan keterampilan proses siswa sebelum dengan setelah menggunakan SSP berbasis inkuiri. Hasil tes menunjukkan bahwa dari 31 siswa uji coba lapangan, 25 siswa (81\%) mengalami peningkatan nilai yang tergolong sedang, dan 6 siswa (19\%) mengalami peningkatan nilai yang tergolong rendah. Berdasarkan data tersebut, dapat disimpulkan bahwa penggunaan SSP berbasis inkuiri dapat meningkatkan keterampilan proses siswa dengan kategori sedang dan rendah.

Tabel 5. Ringkasan Data Skor Keterampilan Proses pada Uji Lapangan

\begin{tabular}{lccc}
\hline \multirow{2}{*}{ Kriteria } & \multicolumn{3}{c}{ Skor Keterampilan Proses } \\
& Pretes & Postes & Gain Standar $(\mathrm{g})$ \\
\hline Skor & 66,7 & 88,9 & 0,7 \\
Tertinggi & & & \\
Skor & 29,6 & 33,3 & 0,1 \\
Terendah & 42,8 & 66,8 & 0,4 \\
Rerata & \\
\hline
\end{tabular}

Data skor keterampilan proses berdasarkan observasi pada masing-masing aspek menun-jukkan bahwa untuk keterampilan merumuskan hipotesis dan menganalisis data, rerata skornya adalah 76 kategori baik. Keterampilan menga-mati mendapatkan skor 78, nilai B dengan kategori baik. Keterampilan mengkomunikasikan mendapatkan skor 82, nilai A dengan kategori sangat baik. Keterampilan menyusun kesimpulan mendapatkan skor 86, nilai A dengan kategori sangat baik. Rerata skor keterampilan proses siswa adalah 79,6 dengan kategori baik. Ber-dasarkan data hasil observasi, dapat disimpulkan bahwa SSP berbasis inkuiri dapat meningkatkan keterampilan proses.

Hal ini sesuai dengan Trowbridge \& Bybee (1986, p.183) yang menyatakan bahwa inkuiri merupakan proses mendefinisikan dan menyelidiki masalah, merumuskan hipotesis, merancang eksperimen, mengumpulkan data, dan membuat kesimpulan tentang masalah tersebut. Collete dan Chiappetta (1994, p.86) juga menyatakan bahwa membelajarkan IPA melalui inkuiri mengarah pada keterampilan dan strategi. Metode ini sering diintegrasikan ke dalam proses pembelajaran untuk mendorong siswa melalui kegiatan-kegiatan berikut: bertanya, keteram-pilan proses IPA, aktivitas induktif, aktivitas deduktif, mengumpulkan informasi dan menye-lesaikan masalah. Martin (2006, p.68) menya-takan bahwa keterampilan proses merupakan bentuk inti inkuiri, yaitu aktivitas dalam pem-belajaran IPA.

To-im \& Ruenwangsa (2009, p.107) menyatakan bahwa inkuiri merupakan sebuah metode yang efektif untuk mengajarkan konten dan keterampilan proses. Bagi guru dan siswa yang memiliki pengalaman sedikit dalam pembelajaran berbasis inkuiri, guided inquiry memberikan lebih banyak struktur dalam pembelajaran.

Hasil penelitian ini juga senada dengan penelitian yang dilakukan oleh Simsek \& Kabapinar (2010, p.1190), yang menyatakan bahwa pembelajaran berdasarkan inkuiri memerikan pengaruh positif terhadap pemahaman konsep dan keterampilan proses siswa. Hasil penelitian tersebut didukung oleh Ergul, et. al. (2011, p.48) yang menyatakan bahwa pembelajaran berdasarkan inkuiri dapat meningkatkan keterampilan proses siswa secara signifikan.

Pembelajaran dengan pendekatan inkuiri tidak hanya menekankan pada pemahaman konsep, tetapi juga keterampilan proses siswa. Yager \& Akcay (Ergul, et. al., 2011, p.49) menyatakan bahwa "inquiry is defined as an approach to teaching, the acts scientist use in doing science and it can be a highly effective teaching methode that help students for to understanding of concepts and proccess skills." Siswa dengan pendekatan inkuiri akan menggunakan keterampilan proses dalam menyelesaikan masalah.

Inkuiri merupakan kegiatan yang terdiri dari pengamatan/observasi, mengajukan perta- 
nyaan, merencanakan penyelidikan, mengumpulkan, menganalisis dan menginterpretasi data, mengajukan jawaban dan penjelasan, prediksi dan mengkomunikasikan hasil. Inkuiri menekankan penggunaan keterampilan proses dasar dan terintegrasi, seperti observasi, mengumpulkan data, eksperimen dan keterampilan proses lainnya dalam pembelajaran IPA.

Berdasarkan uraian di atas, dapat disimpulkan bahwa kegiatan inkuiri dalam pembelajaran IPA tidak dapat dipisahkan dengan keterampilan proses. Pembelajaran yang menggunakan pendekatan inkuiri berarti menggunakan keterampilan proses dalam implementasinya.

\section{Hasil Motivasi Belajar IPA}

Data motivasi belajar IPA siswa dalam penelitian ini diperoleh melalui dua cara, yaitu melalui angket dan observasi. Angket pada uji coba terbatas diberikan setelah pembelajaran menggunakan SSP berbasis inkuiri. Hasil angket menunjukkan bahwa motivasi belajar IPA siswa setelah menggunakan SSP berbasis inkuiri adalah 1 siswa (8\%) mempunyai motivasi belajar yang sangat tinggi, 10 siswa (84\%) mempunyai motivasi belajar yang tinggi, dan 1 siswa (8\%) mempunyai motivasi belajar IPA yang cukup. Rerata skor motivasi belajar IPA siswa adalah 74,4 dengan kategori tinggi.

Hasil observasi digunakan sebagai data pendukung angket motivasi belajar IPA. Hasil observasi menunjukkan bahwa dari 12 subjek coba, terdapat 1 siswa (8\%) mempunyai motivasi belajar yang sangat tinggi, 9 siswa (75\%) mempunyai motivasi belajar yang tinggi, dan 2 siswa (17\%) mempunyai motivasi belajar IPA yang cukup. Rerata skor motivasi belajar IPA berdasarkan observasi adalah 71,7 dengan kategori tinggi.

Angket motivasi belajar pada uji lapangan diberikan sebelum dan sesudah pembelajaran, sehingga dapat dicari besarnya gain standar. Gain standar digunakan untuk mengetahui pening-katan motivasi belajar siswa, ringkasan skor angket motivasi belajar disajikan pada Tabel 6.

Tabel 6. Ringkasan Data Skor Angket Motivasi Belajar IPA Siswa

\begin{tabular}{lccc}
\hline \multirow{2}{*}{ Kriteria } & \multicolumn{3}{c}{ Skor Motivasi Belajar IPA } \\
& Pretes & Postes & Gain Standar (g) \\
\hline Nilai & 75 & 88 & 0,2
\end{tabular}

\begin{tabular}{lccc}
\hline Tertinggi & & & \\
Nilai & 36 & 48 & 0,1 \\
Terendah & 52,6 & 65,0 & 0,2 \\
Rerata & 5,6 \\
\hline
\end{tabular}

Tabel 6 menunjukkan rerata skor motivasi belajar IPA siswa sebelum menggunakan SSP berbasis inkuiri adalah 52,6 dengan kategori rendah. Setelah pembelajaran menggunakan SSP ber-basis inkuiri, skor rerata motivasi belajar IPA siswa adalah 65,0 dengan kategori cukup. Ber-dasarkan selisih rerata skor pretes dengan postes motivasi belajar IPA diketahui ada peningkatan rerata sebesar 12,4.

Hasil angket menunjukkan bahwa dari 31 siswa uji coba lapangan, 5 siswa (19\%) mengalami peningkatan nilai yang tergolong sedang, dan 26 siswa (81\%) mengalami peningkatan nilai yang tergolong rendah. Berdasarkan data terse-but, dapat disimpulkan bahwa penggunaan SSP berbasis inkuiri dapat meningkatkan motivasi belajar IPA siswa dengan kategori sedang dan rendah.

Hasil observasi motivasi belajar IPA siswa menunjukkan bahwa dari 31 subjek coba, ter-dapat 4 siswa (13\%) mempunyai motivasi belajar yang sangat tinggi, 6 siswa (19\%) mempunyai motivasi belajar yang tinggi, 14 siswa $(45 \%)$ mempunyai motivasi belajar IPA yang cukup, 6 siswa (19\%) mempunyai motivasi belajar IPA yang rendah, dan 1 siswa (3\%) mempunyai moti-vasi belajar yang sangat rendah. Rerata skor motivasi belajar IPA berdasarkan observasi adalah 63,66 dengan kategori cukup.

Chiappetta \& Koballa (2010, p.123) menyatakan bahwa inkuiri menandai proses aktif yang terlibat dalam pemikiran imiah, investigasi, dan konstruksi dari pengetahuan. Pendekatan inkuiri ditandai dengan adanya pencarian jawaban yang mensyaratkan siswa melakukan serangkaian kegiatan intelektual agar penga-laman atau masalah dapat dipahami. Inkuiri menekankan adanya inisiatif dari siswa untuk mengalami proses belajarnya sendiri.

Salah satu pendekatan pembelajaran yang dapat digunakan untuk memotivasi siswa dalam pembelajaran serta membangun pengetahuan dari hasil konstruksi pengalaman dengan pengetahuan sebelumnya adalah pendekatan inkuiri. Inkuiri melibatkan siswa dalam merekonstruksi dan merefleksikan pengetahuan dalam pembelajaran. Inkuiri juga merupakan pendekatan penyelidikan untuk memotivasi siswa dalam mengemukakan ide-ide menciptakan pembelajaran yang menarik. Sejak 
pembelajaran dimulai, siswa dipicu motivasinya dengan cara demonstrasi, pertanya-an. Umpan balik dan penghargaan dari pendidik membuat siswa dihargai sehingga lebih ber-semangat dan berani mengemukakan pendapat. Pendekatan inkuiri memberikan kesempatan kepada siswa untuk unjuk kerja, unjuk kemam-puan mempresentasikan hasil, serta bekerja sama dengan kelompok untuk melakukan penyelidikan.

Hasil penelitian ini juga sesuai dengan penelitian yang dilakukan oleh Tuan, Chin, \& Shieh (2005b, p.559), menyatakan inkuiri dapat meningkatkan motivasi belajar IPA dari aspek kepercayaan diri siswa, strategi pembelajaran aktif, dan nilai belajar IPA. Pembelajaran berbasis inkuiri memberikan kesempatan kepada siswa untuk menyelidiki dan membangun penge-tahuan yang bermakna. Siswa dalam kegiatan inkuiri mempunyai kewenangan untuk memilih, mengatur diri, dan berkesempatan mengerjakan proyek yang menarik bagi siswa. Kegiatan inkuiri juga menyediakan tantangan dan tugas yang berarti apabila siswa terlibat didalamnya.

Glynn \& Koballa (2006, p.29) menyatakan bahwa salah satu cara untuk meningkatkan motivasi belajar IPA adalah dengan meng-gunakan kegiatan inkuiri. Madden (2011, p.30) dalam penelitiannya menyatakan bahwa strategi pembelajaran inkuiri berhasil meningkatkan motivasi siswa dan juga membantu dalam kelas yang lebih tinggi. Kane (2013, p.163) menya-takan bahwa inkuiri menimbulkan motivasi siswa, membantu siswa menyimpan pengetahuan dengan lebih baik. Siswa mengembangkan kete-rampilan inkuiri dan termotivasi untuk mening-katkan kemampuannya.

Pendekatan inkuiri memberikan kesempat-an kepada siswa untuk melakukan kegiatan pembelajaran yang menawarkan usaha dan tan-tangan dalam belajar untuk menemukan berbagai kemungkinan jawaban, melalui percobaan dan penyelidikan, dan membangkitkan rasa ingin tahu dengan berbagai pertanyaan. Siswa dengan inkuiri dapat termotivasi dalam belajar IPA.

\section{Keterlaksanaan Pembelajaran}

Ringkasan data skor keterlaksanaan pembelajaran ketiga RPP disajikan pada Tabel 7 . Berdasarkan Tabel 7 diketahui bahwa pada uji coba terbatas pertemuan 1, ada tahapan kegiatan yang belum terlaksana maksimal. Tahapan menganalisis data, siswa kekurangan waktu untuk menganalisis data karena data pengamatan terlalu banyak. Pertemuan 2 dan 3 tahapan yang belum maksimal adalah mengumpulkan dan menganalisis data. Ketidakterlaksanaan tahapan ini karena terlalu banyak kegiatan yang harus dikerjakan siswa. Secara umum dapat dikatakan bahwa RPP pada pertemuan 1, 2, dan 3 dapat terlaksana dengan cukup baik.

Tabel 7. Data Skor Keterlaksanaan Pembelajaran

\begin{tabular}{cclc}
\hline RPP & Skor & Kriteria & \% Reliabilitas \\
\hline Uji Terbatas & & \\
1 & 70 & Baik & 80 \\
2 & 58 & Cukup baik & 80 \\
3 & 62 & Cukup baik & 80 \\
Uji Lapangan & & \\
1 & 98 & Sangat baik & 80 \\
2 & 98 & Sangat baik & 80 \\
3 & 100 & Sangat baik & 100 \\
\hline
\end{tabular}

Berdasarkan Tabel 7 juga diketahui bahwa pada uji coba lapangan nilai untuk keterlaksanaan pembelajaran adalah A dengan kategori sangat baik. Berdasarkan penilaian tersebut, dapat dikatakan bahwa seluruh komponen RPP dilaksanakan guru dengan baik. Nilai reliabilitas (KK) RPP pertemuan 1 dan 2 adalah $80 \%$, dan pertemuan 3 adalah $100 \%$. Instrumen pengamatan yang baik adalah instrumen yang mempunyai nilai reliabilitas lebih besar atau sama dengan $75 \%$.

\section{Respon Siswa Terhadap SSP}

\section{Respon Siswa Terhadap Pembelajaran (RPP)}

Respon siswa diperoleh dari angket yang diberikan pada akhir pembelajaran. Data skor respon siswa terhadap proses pembelajaran ditampilkan pada Tabel 8.

Tabel 8. Data Respon Siswa Terhadap Pembelajaran

\begin{tabular}{cccl}
\hline Uji & Skor & Nilai & \multicolumn{1}{c}{ Kategori } \\
\hline Terbatas & 84,81 & A & Sangat setuju \\
Lapangan & 77,80 & B & Setuju \\
\hline
\end{tabular}

Respon siswa terhadap pelaksanaan RPP pada uji coba terbatas menunjukkan bahwa siswa sangat setuju dengan penerapan komponenkomponen RPP dalam pembelajaran yang disampaikan guru. Siswa juga sangat setuju bahwa pembe-lajaran dapat meningkatkan keterampilan proses dan motivasi belajar IPA.

Respon siswa terhadap pelaksanaan RPP pada uji coba lapangan menunjukkan bahwa 
siswa setuju dengan penerapan komponenkomponen RPP dalam pembelajaran yang disampaikan guru. Siswa juga setuju bahwa pembelajaran dapat meningkatkan keterampilan proses dan motivasi belajar IPA. Secara umum dapat dikatakan bahwa siswa setuju dengan proses pembelajaran yang dilakukan guru.

\section{Respon Siswa Terhadap LKS}

Data skor respon siswa terhadap LKS disajikan pada Tabel 9. Secara umum, dapat dinyatakan bahwa siswa setuju dengan LKS yang digunakan dalam pembelajaran IPA.

Tabel 9. Data Skor Respon Siswa Terhadap LKS

\begin{tabular}{lccc}
\hline \multicolumn{1}{c}{ Uji } & Skor & Nilai & Kategori \\
\hline Terbatas & 76,60 & B & Setuju \\
Lapangan & 72,20 & B & Setuju \\
\hline
\end{tabular}

\section{SIMPULAN}

Berdasarkan hasil penelitian dan pengembangan SSP berbasis inkuiri, dapat disimpulkan sebagai berikut: (1) SSP yang dikembangkan ditinjau dari komponen silabus, RPP, LKS, dan lembar penilaian siswa, layak digunakan dalam pembelajaran IPA di SMP menurut ahli, guru IPA, dan teman sejawat; (2) SSP yang dikembangkan dapat meningkatkan keterampilan proses siswa, yaitu keterampilan merumuskan hipotesis, mengamati, menganalisis data, mengkomunikasikan, dan menyusun kesimpulan; serta (3) SSP yang dikembangkan dapat meningkatkan motivasi belajar IPA siswa pada aspek tingkat keyakinan diri siswa, strategi pembelajaran aktif, nilai belajar IPA, tujuan belajar IPA, tujuan prestasi, dan lingkungan pembelajaran.

Berdasarkan hasil, temuan, dan keterbatasan penelitian yang telah dilakukan, peneliti menyarankan hal-hal sebagai berikut: (1) guru berlatih menggunakan pembelajaran berbasis inkuiri sehingga dalam pelaksanaannya dapat lancar dan efisien; (2) SSP berbasis inkuiri ini dapat didiseminasikan kepada guru IPA yang lain melalui sekolah dan forum Musyawarah Guru Mata Pelajaran (MGMP).

\section{DAFTAR PUSTAKA}

Azwar, S. (2011). Tes prestasi (fungsi dan pengembangan pengukuran prestasi belajar). Yogyakarta: Pustaka Pelajar.

Bundu, P. (2006). Penilaian keterampilan proses dan sikap ilmiah dalam pembelajaran sains-SD. Jakarta: Depdiknas.

Carin, A. A. \& Sund, R. B. (1993). Teaching science through discovery. Toronto: Merril Publishing Company.

Chang, I. Y., Chang, W. Y. (2012). The effect of student learning motivation on learning satisfaction. The International Journal of Organizational Innovation, 4 (3), 281-305.

Chiappetta, E. L. \& Koballa, T. R. (2010). Science instruction in the middle and secondary schools $\left(7^{\text {rd }}\right.$ ed). New York: Allyn \& Bacon.

Collete, A. T. \& Chiappeta, E. L. (1994). Science instruction in the middle and secondary schools. New York: Macmillan Publishing Company.

Dell'Olio, J. M. \& Donk, T. (2007). Models of teaching connecting student learning with standars. New Delhi: Sage Publications.

Depdiknas. (2008). Panduan umum pengembangan silabus. Jakarta: Depdiknas.

Elliot, S. N., Kratochwill, T. R., Cook, J. L., \& Travers, J. F. (2000). Educational psychology: effective teaching, effective learning $\left(3^{\text {th }}\right.$ ed.). Boston, MA: Mc Graw Hill.

Ergül, R., Şimşekli, Y., Çalis, S., Özdilek, Z., Göçmencelebi, Ş., Şanli, M. (2011). The effects of inquiry-based science teaching on elementary school students' science procces skills and science attitude. Bulgarian Journal of Science and Education Policy, 5, 48-68.

Gall, M. D., Gall, J. P., \& Borg, W. R. (2007). Educational research: An introduction $\left(8^{\text {th }} e d\right.$.). New York: Logman.

Glynn, S. M., Koballa, T. R., Jr. (2006). Motivation to learn college science. Dalam Joel J. Mintzes \& William H. Leonard (Eds). Handbook of College Science Teaching. Arlington, VA: National Science Teachers Association Press. 
Hake, R. R. (1998). Interactive engagement vs traditional methods: A six-thousandstudent-survey of mechanic test data for introductory physics course. The American Journal of Physics Research, 66, 64-74.

Harlen, W. (1999). Purposes and procedure for assessing process skills. Assessment in education, 6 (1), 129-144.

Harlen, W., \& Crick, R. D. (2003). Testing and motivation for learning. Assessment in Education, 10 (2), 169-206.

Herr, N. (2007). What is PCK?. Diambil pada 10 September 2013, dari http://www.csun.edu/science/ref/pedago gy/pck/index.html.

Joyce, B., Weil, M., \& Calhoun, W. E. (2004). Models of teaching $\left(7^{\text {th }}\right.$ ed.). Boston, MA: Pearson Education.

Kane, E. M. K. (2013). Urban student motivation through inquiry-based learning. Journal of Studies in Education, 3 (1), 155-168.

Karamustafaoglu, S. (2011). Improving the science process skills ability of science student teachers using I diagram. Eurasian Journal Physic And Chemistry Education, 3(1), 26-38.

Keil, C., Haney, J. \& Zoffel. J. (2009). Improvements in student achievement and science process skills using enviromental health science problembased learning curricula.. Electronic Journal of Science Education, 13 (1), 18.

Kemdikbud. (2013). Lampiran Peraturan Menteri Pendidikan dan Kebudayaan Republik Indonesia Nomor 65 Tahun 2013, tentang Standar Proses Pendidikan Dasar dan Menengah.

Koehler, M. J., \& Mishra, P. (2009). What is technological pedagogical content knowledge? Contemporary Issues in Technology and Teacher Education, 9 (1), 60-70.

Loughran, J., Berry A., Mulhall, P. (2006). Understanding and developing science teachers' pedagogical content knowledge. Rotterdam: Sense Publishers.

Madden, K. R. (2011). The use of inquiry-based instruction to increase motivation and academic success in a high school biology classroom. Tesis master, tidak diterbitkan, Montana State University, Bozeman, Montana.

Martin, D. J. (2006). Elementary science methods. A constructivist approach $\left(4^{\text {th }}\right.$ ed). Belmont, CA: Thomson.

McCormack, A.J. (1992). Trends and issues in science curriculum. Dalam D. W. Cheek, R. Briggs, \& R. E. Yager (Eds), Science Curriculum Resource Handbook A Practical Guide for K-12 Science Curriculum (pp.16-41). New York: Kraus International Publications.

Meltzer, D. E. (2002). The relationship between mathematic preparations and conceptual learning gain in physics: a possible "hidden variabel" in diagnostic pretest scores. American Journal Physics, 70 (12), 1259-1267.

Moore, K.D. (2009). Effective instructional strategies from theory to practice. Los Angeles: Sage.

Noor, F. M., \& Wilujeng, I. (2015). Pengembangan SSP fisika berbasis pendekatan CTL untuk meningkatkan keterampilan proses sains dan motivasi belajar. Jurnal Inovasi Pendidikan IPA, 1 (1), $73-85$.

Ormrod, J. E. (2003). Educational psychology developing learners $\left(4^{\text {th }} e d\right)$. New Jersey: Merril Prentice Hall.

Padilla, M. J. (1990). The science process skills Research Matter-to The Science Teacher, 9004, 1-4.

Rezba, R. J., Sparague, C. S., Field, R. L., Funk, H. J., Okey, J. R., Jaus, H. H. (1995). Learning and assesing science process skills. Iowa: Kendall/Hunt Publishing Company.

Schunk, D. H., Pintrich, P. R., \& Meece, J. L. (2010). Motivation in education $\left(3^{\text {rd }}\right.$ ed.). London: Pearson Education.

Semiawan, C., Tangyong, A. F., Matahelemual, Y., \& Suseloardjo, W. (1989). Pendekatan keterampilan proses, bagaimana mengaktifkan siswa dalam belajar. Jakarta: PT Gramedia.

Shulman, L. S. (1987). Knowledge and teaching: foundations of the new reform. Harvard Educational Review, 57, 1-22. 
Simsek, P., \& Kabapinar, F. (2010). The effect of inkuiri-based learning on elementary student's conceptual understanding of matter, scientific procces skills and science attitude. Procedia-Social and Behavorial Sciences, 2, 1190-1194.

Solis, A. (2011). Pedagocical content knowledge what matters most in the professional learning of content teachers in classrooms with diverse student populations. Diambil pada tanggal 20 oktober 2013, dari http://www.idra.org/IDRA_Newsletter/ August 2009 Actionable Knowledge/P edagogical Content Knowledge/\#sthas h.XsFQmsoK.dpuf.

Suharsimi, A. (2010). Prosedur penelitian suatu pendekatan praktik. Jakarta: Rineka Cipta.

Supriana. (2010). Implementasi pembelajaran IPA terpadu di SMP negeri kota Yogyakarta. Tesis Magister, tidak diterbitkan, Universitas Negeri Yogyakarta, Yogyakarta.

Tom-in, J., \& Ruenwangsa, P. (2009). Guided inquiry learning unit on aquatic ecosystems for seventh grade students. Journal of Natural Resources \& life Science Education, 38.
Trowbridge, L. W., \& Bybee, R.W. (1986). Becoming a secondary school science teacher. Columbus: Merril Publishing Company.

Tuan, H. L., Chin, C. C., \& Shieh, S. H. (2005a). The development of a questionnaire to measure students' motivation towards science learning. International Journal of Science Education, 27 (6), 639-654.

Tuan, H. L., Chin, C. C., \& Shieh, S. H. (2005b). Investigating the effectiveness of inquiry instruction on the motivation of different learning styles students. International Journal of Science and Mathematics Education, 3, 541-566.

Widoyoko, E. P. (2012). Teknik penyusunan instrumen penelitian. Yogyakarta: Pustaka Pelajar.

Woolfolk, A. (2007). Educational psyshology $\left(10^{\text {th }}\right.$ ed.). New York: Pearson Education.

\section{PROFIL SINGKAT}

SETITI HANDAYANI adalah Guru IPA SMP negeri 2 Kembang Jepara, lahir di Pati, 21 Oktober 1975. Lulusan Program Pascasarjana Universitas Negeri Yogyakarta program Studi Pendidikan Sains Tahun 2014. Lulusan S1 dari Jurusan Ilmu Tanah Universitas Pembangunan Nasional "Veteran" Yogyakarta Tahun 1999. 